\title{
Risk of Repeat Surgery for Perianal Crohn Disease
}

\author{
Doo Han Lee \\ Department of Surgery, Daehang Hospital, Seoul, Korea
}

\section{See Article on Page 176-181}

Perianal involvement of Crohn disease (CD) is known to be a common complication of $\mathrm{CD}$. Due to the wide variety of anal manifestations of $\mathrm{CD}$, the exact prevalence of perianal Crohn disease (PCD) is not known. However, it is estimated that a majority of patients with $\mathrm{CD}$ may undergo surgical treatment for PCD. The most common causes of operative treatment are perianal abscesses and anal fistulas because surgical treatment is mandatory to control acute sepsis. Contrary to fistulas of a cryptoglandular origin, those of $\mathrm{CD}$ are different in terms of pathogenesis and clinical course. Due to the unpredictable clinical course and increased risk of recurrence, conservative treatment is generally accepted to be more appropriate for treating patients with PCD. Repeated surgical treatment may deteriorate continence, which results in decreased quality of life for the patient. Therefore, an estimate of the clinical course and a prediction of recurrence after surgical treatment have clinical significance in the treatment of patients with PCD. Despite the clinical importance of PCD, literature concerning the risk factors of repeat surgical treatment for PCD is scarce.

A recent retrospective study reported the cumulative risks of reoperation for patients operated on for PCD, as well as the related risk factors [1]. According to the study, the risk of reoperation increases during the disease's course, reaching up to $50 \%$ after the first surgical treatment, and risk factors associated with reoperation are a young age at the onset of $\mathrm{CD}$, a history of abdominal surgery for $\mathrm{CD}$, and the type of surgery. Although some controversies may exist, the risk of reoperation most likely increases in proportion to the time. Therefore, early onset of CD may be related with an increased risk of reoperation for PCD. Also, considering that the clinical course of $\mathrm{CD}$ with fistulizing PCD seems to

Correspondence to: Doo Han Lee, M.D.

Department of Surgery, Daehang Hospital, 2151 Nambusunhwan-ro, Seocho-gu, Seoul 06699, Korea

Tel: +82-2-6388-8118, Fax: +82-2-6388-8115

E-mail:dhlee@daehang.com

(c) 2015 The Korean Society of Coloproctology

This is an open-access article distributed under the terms of the Creative Commons Attribution NonCommercial License (http://creativecommons.org/licenses/by-nc/3.0) which permits unrestricted noncommercial use, distribution, and reproduction in any medium, provided the original work is properly cited. be more aggressive, patients with abdominal surgery may have aggressive PCDs. Concerning surgical treatment, conservative treatment is recommended. However, a curative treatment such as a fistulotomy can be done in selected cases [2]. Compared with incision and drainage or seton placement, a fistulotomy or a fistulectomy would reduce the risk of reoperation because of the its radical characteristics. However, the choice of radical treatment should be prudent because of sphincter division, the risk of incontinence, and compromised wound healing. While this study is a clinically significant attempt to investigate factors related with repeat surgery, it lacks data regarding whether and how the usage of a biologic agent influences the clinical course of PCD. Some reports showed the effectiveness of using the anti-tumor necrosis factor (TNF) antibody in fistula healing for Crohn anal fistulas [3, 4]. Although anti-TNF therapy seems to be promising, a multidisciplinary approach is mandatory because surgical treatment is essential to control acute sepsis and may be a preliminary procedure to enhance the effect of medical treatment.

\section{CONFLICT OF INTEREST}

No potential conflict of interest relevant to this article was reported.

\section{REFERENCES}

1. Lee JB, Yoon SG, Park KJ, Lee KY, Kim DD, Yoon SN, et al. Clinical features and predictive risk factors for reoperation in patients with perianal Crohn disease: a multi-center study by a Korean Inflammatory Bowel Disease Study Group. Ann Coloproctol 2015; 31:176-81.

2. Lee IS, Choe EK, Park SC, Park KJ. Crohn's anal fistula and perianal abscess: results of surgical treatment. J Korean Soc Coloproctol 2007;23:424-30.

3. Present DH, Rutgeerts P, Targan S, Hanauer SB, Mayer L, van Hogezand RA, et al. Infliximab for the treatment of fistulas in patients with Crohn's disease. N Engl J Med 1999;340:1398-405.

4. Ng SC, Plamondon S, Gupta A, Burling D, Swatton A, Vaizey CJ, et al. Prospective evaluation of anti-tumor necrosis factor therapy guided by magnetic resonance imaging for Crohn's perineal fistulas. Am J Gastroenterol 2009;104:2973-86. 